\title{
パワエレにおける時間周波数解析の適用
}

\author{
道平雅一 橋本卓也 森田二朗 津吉彰 尼子邦之 大江武彦 \\ (神戸市立工業高等専門学校)
}

\section{Application of Time-Frequency Analysis for Power Electronics}

\author{
Masakazu MICHIHIRA, Takehiko OE, Kazushi HISAYAMA \\ Kuniyuki AMAKO, Akira TSUYOSHI (Kobe C.C.T.)
}

\begin{abstract}
In recent years, the harmonics and EMI noise sent out from an electric power conversion system are getting a great deal of attention in electromagnetic environment problems. The considerations of this problem have been getting important by recent significant improvement of auto-arc-suppressing device and switching speed. Therefore, there is need to do a detail frequency analysis such as transient phenomena. So, we have proposed the analytic technique using Wavelet-transform which is possible to catch a phenomenon from the both sides of the time and the frequency. In this paper, we analysed the actual measured data in the switching interval by using Wavelet-transform. Then, based on obtained result, we describe the validity of Wavelet-transform and the application to the power electronics field.
\end{abstract}

Keywords : EMI noise, Wavelet-transform, Fourier-transform, power converter

\section{1. まえがき}

電力用半導体デバイスをスイッチングさせて電圧、電流 または電力をコントロールするパワエレ機器は、程度の 差はあれ原理的に高調波や EMI ノイズを発生する。省工 ネルギーや制御の高度化にはパワエレ機器は非常に有効 なものであり、今後も一層の普及が予想される。従って、 それらから発生する高調波やEMI ノイズに対して十分考 慮しなければ EMC(Electro Magnetic Compatibility：電 磁環境両立性) 問題を新たに生じさせる恐れがあり、電磁 環境問題対策はパワエレ分野における最重要課題となり つつある。

的確で効率的な高調波や EMI ノイズ対策を施すために はそれらの発生箇所の特定や伝搬の様子も把握すること が重要になると考えられるが、現在、周波数解析で主に 用いられているフーリエ変換による周波数解析では、時 間情報が失われるためそれらを望むことはできない。こ れに代わる解析手法として、ウェーブレット変換による 時間周波数解析を適用すると、スイッチングに伴う現象 を時間と周波数の両面から捉えることができるようにな るため、時間経過とともに現象が変化するような時系列 信号の解析に適していると考えられる。これは、パワエ レ機器が発する高調波の瞬時值解析が可能になることに なり、EMC 問題に対する新たな知見も得られると考えら れる。本論文では、これまでに変換器内部の高調波発生 過程や、その伝達形態の解明を試みた結果を紹介すると ともに、ウェーブレット変換のパワーエレクトロニクス 分野への応用とその有効性について報告する。

\section{2. ウェーブレット変換手法}

ウェーブレット変換は、後述するマザーウェーブレッ トと呼ばれる基底関数により連続ウェーブレット変換と 離散ウェーブレット変換に大別される。連続ウェーブレッ 卜変換は、時間周波数解析であるという特徴を利用して 時系列のデータ分析に、離散ウェーブレット変換は多重 解像度解析であるという特幑を利用した画像圧縮と符号 化の分野へ応用されている。ここでは、今回適用してい る連続ウェーブレット変換について述べる (以後、連続 ウェーブレット変換のことを単にウェーブレット変換と記 述する)。ウェーブレット変換に用いられる関数 $\psi(t)$ は、 ウェーブレット変換の全てを特幑づける重要な関数で、マ ザーウェーブレットあるいはアナライジングウェーブレッ トと呼ばれており、局在を表す $(1)$ 式の条件を満たしてい る。ここで $\hat{\psi}(\omega)$ は $(2)$ 式に示す $\psi(t)$ のフーリエ変換で ある。一般に用いられるような遠くで速くゼロになる関 数に関しては、同值となる(3) 式が用いられる。(3) 式は、 $\psi(t)$ が直流成分を持たない、すなわち振動的であるとい うことを示している。

$$
\begin{gathered}
C_{\psi} \equiv \int_{-\infty}^{\infty} \frac{|\hat{\psi}(\omega)|^{2}}{|\omega|} d \omega=\text { 有限 } \\
\hat{\psi}(\omega)=\int_{-\infty}^{\infty} e^{-j \omega t} \psi(t) d t \\
\int_{-\infty}^{\infty} \psi(t) d t=0
\end{gathered}
$$

ウェーブレット変換の基底関数であるマザーウェーブ レット $\psi(t)$ には幾つかの種類があるが、本研究では現象 


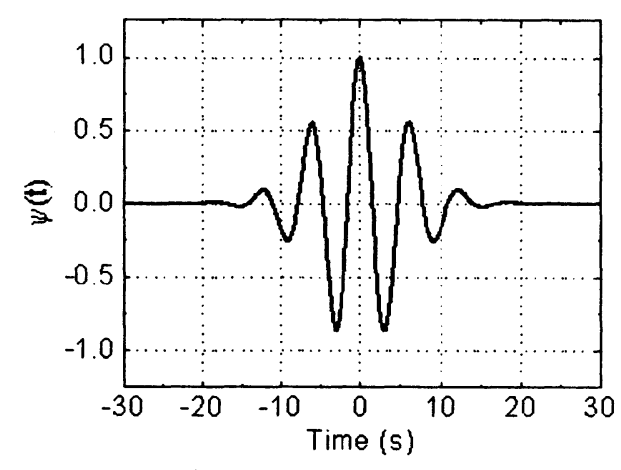

図1.マザーウェーブレットの実数部

の生起時間などの不連続点を的確に捉えることができる という特長を持ち、連続ウェーブレット変換において広く 用いられている Gabor のマザーウェーブレット ((4) 式) を適用している。このマザーウェーブレットは、時間及 び周波数領域での不確定性の積を最小にする関数として 知られており、無駄の少ない時間周波数解析を可能とし ている。(4) 式の $\sigma$ は、時間軸上におけるマザーウェー ブレットの局在性、すなわち空幅を決定する定数であり、 対象とする時間及び周波数の解析範囲に応じてそれぞれ の領域における不確定性関係を十分に考虑し決定する必 要がある。本研究では、解析対象の波形に対して試行錯 誤的に得た妥当と見なせる $\sigma=8$ を用いた。(4) 式の実数 部分を図 1 に示す。

$$
\psi(t)=\frac{1}{2 \sqrt{\pi} \sigma} e^{-\frac{t^{2}}{\sigma^{2}}} e^{-i t}
$$

ウェーブレット変換は、図 1 に示すようなマザーウェー ブレットを横方向に拡大・縮小しながら時間軸上で移動 させ、それと信号との積をとることにより局所的な周波 数を切り出している。つまりウェーブレット変換は、この 拡大・縮小・移動を行うため変数 $t$ をスケールパラメータ $a$ とトランスレートパラメータ $b$ により $(t-b) / a$ と置き 換えて、マザーウェーブレットを $\psi\left(\frac{t-b}{a}\right)$ とした関数の組 $\psi_{a, b}(t)$ 、すなわち、(5) 式を積分核とした積分変換により 行われる ((6) 式)。ここで $1 / a$ は周波数を意味し、 $b$ は横 軸の平行移動、すなわち時間軸上におけるマザーウェー ブレットの中心位置であることを意味している。ここで $1 / \sqrt{a}$ は各スケール・パラメータにおいて同一のエネル ギーとなるための正規化定数である。従って、関数 $f(t)$ のウェーブレット変換係数 $W_{\psi}(a, b)$ は $(7)$ 式のように定 義される。

$$
\begin{aligned}
\psi_{a, b}(t) & =\frac{1}{\sqrt{a}} \psi\left(\frac{t-b}{a}\right) \\
W_{\psi}(a, b) & =\int_{-\infty}^{\infty} \psi_{a, b}^{*}(t) f(t) d t \\
& =\int_{-\infty}^{\infty} \frac{1}{\sqrt{a}} \psi^{*}\left(\frac{t-b}{a}\right) f(t) d t
\end{aligned}
$$

これらの定義により行うウェーブレット変換は、時系列 データとマザーウェーブレットとの相関処理及びフーリ
エ空間におけるフィルタリングを行うことになるため次 のような特徴を持つことになる。

1. 高周波成分に対して、時間分解能が高く周波数分解 能が低い。また、低周波成分に対して、時間分解能 が低く周波数分解能が高い

2. マザーウェーブレットが局在化した関数であり、直 流成分を含まないため信号の不連続点を敏感に捉え ることができる。

以上のことから、ウェーブレット変換が信号の不確定性 関係を考慮に入れた最も無䭾の少ない時間周波数解析で あることが分かる。

2.1 テスト波形によるウェーブレット変換とフーリエ変 換の比較 ここでは、フーリエ変換による周波数解析結 果とウェーブレット変換による時間周波数解析結果の比 較検討を行うため、図 $2(\mathrm{a})$ に示す変換器出力波形を想定

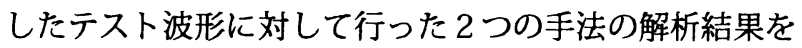
示す。

表 1 テスト波形の時間周波数構成

\begin{tabular}{|c|c|c|c|}
\hline & 次数 (th) & 時間 (p.u.) & 振幅 (p.u.) \\
\hline & 1 & $0 \sim 1$ & 1.0000 \\
\hline & 40 & $0 \sim 1$ & 0.0250 \\
\hline & 100 & $0.4 \sim 1$ & 0.0525 (減衰波) \\
\hline & 180 & $0.5 \sim 0.525$ & 0.1250 \\
\hline
\end{tabular}

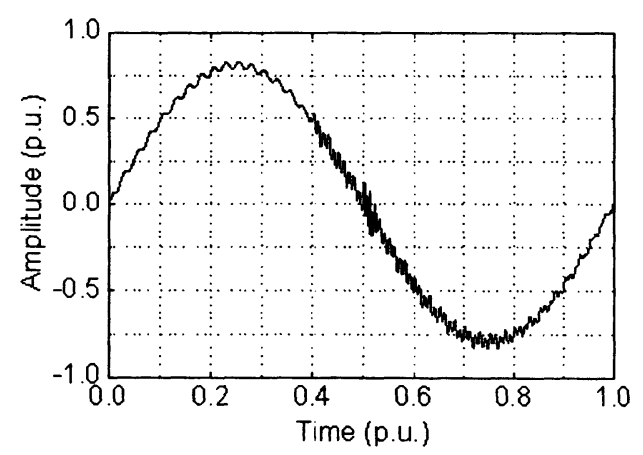

(a) デスト波形

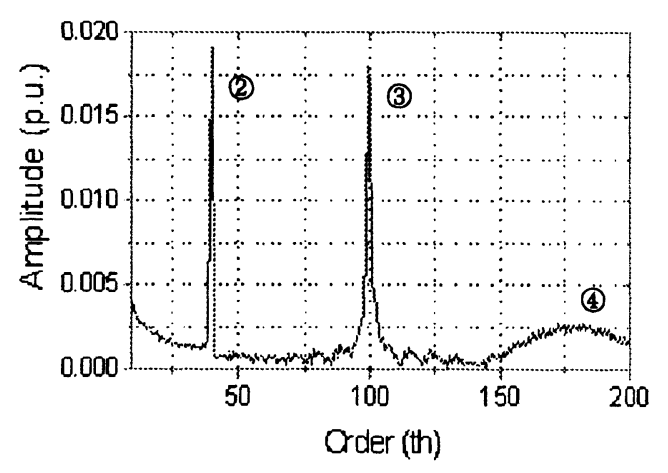

(b) フーリエスペクトラム

図 2 テスト波形 


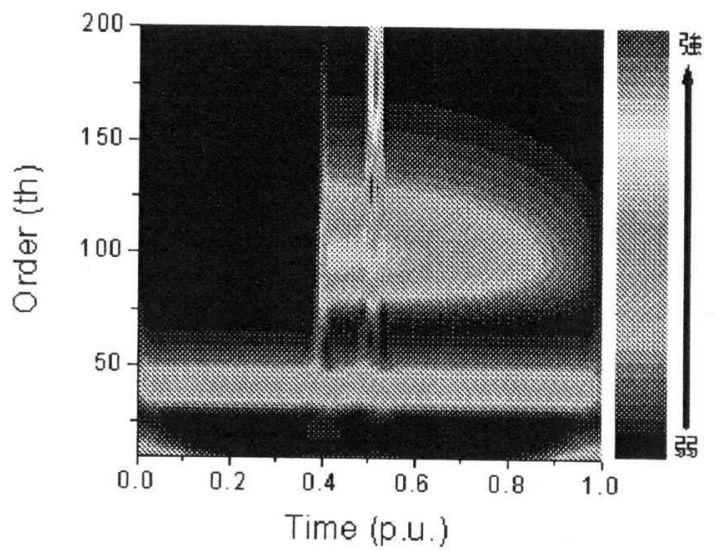

図 3 デスト波形の時間周波数解析結果 (等高線表示)

用いたテスト波形は、表 1 に示すような周波数と現象 開始時間を持つ異なる 4 つの波形を合成したものを用い た。図 2(b) は通常のフーリエ解析結果、図 3、4 はウェ一 ブレット解析結果を示す。フーリエ解析結果からは、

$40 \mathrm{MHz} 、 100 \mathrm{MHz}$ の振幅值はほぼ等しくなっているこ とが理解できる。しかし実際は、表 1 に示しているよう に発生時間及び振幅も異なり、さらに $40 \mathrm{MHz}$ の成分は一 定の振幅で発生しているのに対して、100MHz の成分の 振幅は減衰しているがこれらの違いはフーリエ結果から だけでは知ることはできない。また、解析区間内でイン パルス的に発生している $180 \mathrm{MHz}$ の成分は、図 2(b) の フーリエ解析結果からはその存在を認識することは困難 である。

一方、ウェーブレット解析結果からは、表 1 に示すよ うに $40 \mathrm{MHz}$ の成分が時間軸に関わらず一定の振幅で発 生し, $100 \mathrm{MHz}$ の成分が $t=0.4$ で発生し減衰していく 様子がはっきりと確認できる。また, $180 \mathrm{MHz}$ の成分が $t=0.5 \sim 0.525$ の期間でインパルス的に発生しているこ とも確認できる。さらに、 $t=0.4,0.5,0.525$ の 3 つの点 で現象の不連続点が確認できるが、これは新たな現象の 生起時間であると特定することができる。最後に、フー リ工解析結果とウェーブレット解析結果を比較すると、前 述したようにウェーブレット変換はフーリエ変換より周 波数分解能が劣っていることが分かる。

以上のように、時間周波数解析により得られたこれら の結果は、表 1 に示した現象とよく一致することが理解 できる。これらは、フーリエ解析結果だけでは知ること のできなかった情報であり、ウェーブレット解析を用い た時間周波数解析をパワエレ分野へ適用することは新た な知見を得るために有効であると言える。

\section{3. パワーエレクトロニクス機器から発生する高調波の} 時間周波数解析

ここでは、これまでに電力変換装置から得られたデー 夕に時間周波数解析を行った結果について数例紹介する。

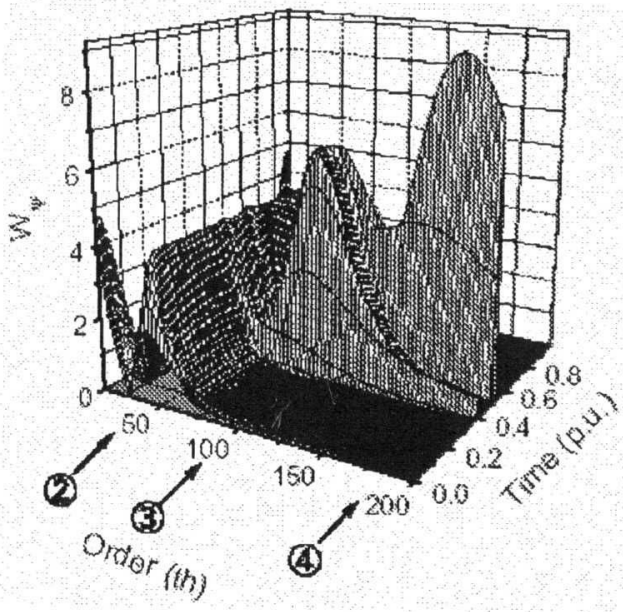

(a) 前面から見た図

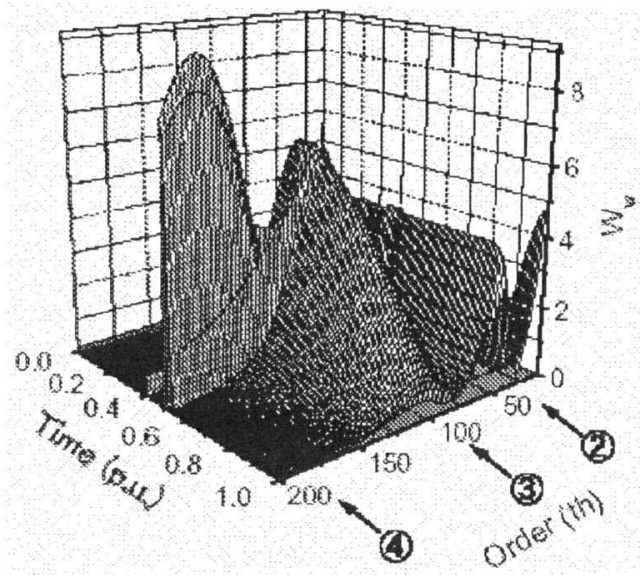

(b) 背從から見た図

図 4 テスト波形の時間周波数解析結果 (3D 表示)

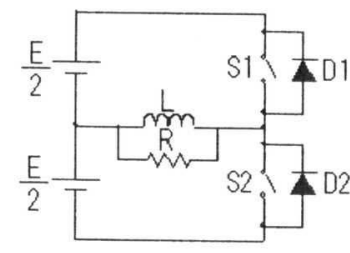

(a) ヘードスイッチンダ

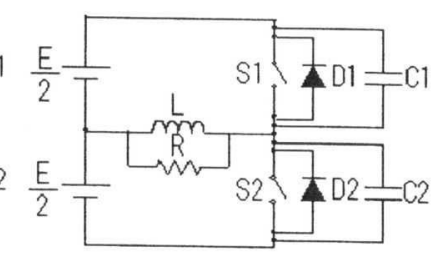

(b) ソフトスイッヂンダ
図 5 ハーフブリッジインバータ回路

3.1 ハードスイッチングとソフトスイッチング パワー エレクトロニクス分野で様々な報告がなされている、ソ フトスイッチング方式とハードスイッチング方式のスイッ チング過渡時の電圧波形についての解析結果を示す。ここ では、比較的構成が簡単なハーフブリッジインバータを製 作し、ハードスイッチングとソフトスイッチング (ZVS : Zero Voltage Switching) それぞれの方式で動作させた時 のスイッチング過渡時の実測波形を測定し高調波解析を 行つた。回路構成は、図 5 に示す通りである。使用した デバイスは IGBT(MG100J2YS50：東芝)、負荷抵抗 R は $6.4 \Omega$ 、インダクタンス L は $650 \mu \mathrm{H}$ 、そしてソフトスイッ 


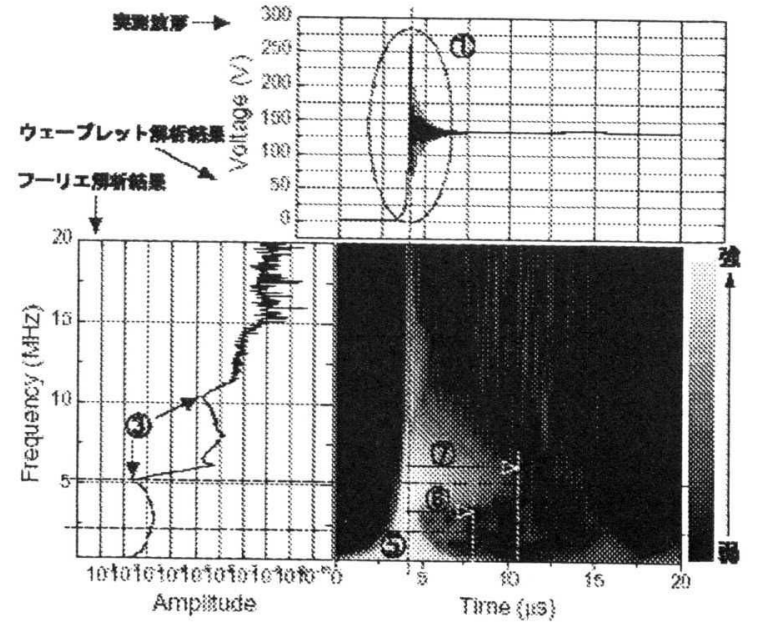

(a)ハードスイッキンダ波形

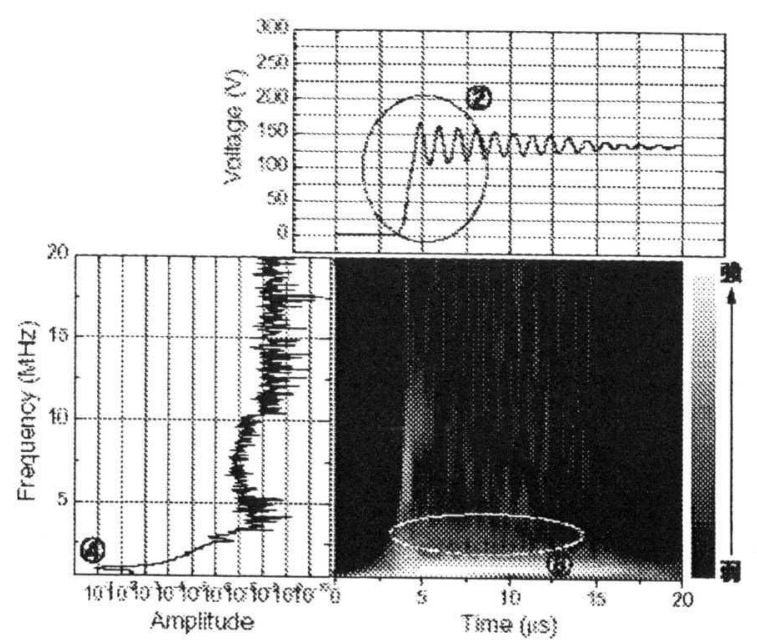

(b) ソフトスイッチンダ (ZVS) 波形

図6 スイッチング電圧波形

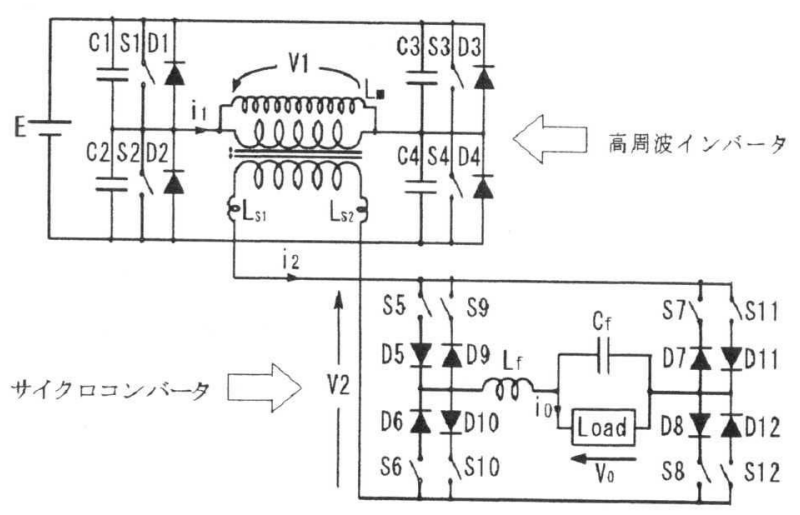

図 7 高周波 $\mathrm{AC}$ リンク DC-AC コンバータ

チング (ZVS) 回路には、それを実現するためにそれぞれ のデバイスに対して並列に $23 \mathrm{nF}$ のコンデンサ $\mathrm{C} 1 、 \mathrm{C} 2$ を 接続した。それぞれの回路に対して同条件の動作を行っ て得られたターンオフ時のデバイスにかかる電圧波形を 図6(a),(b)に示す。各図とも実測波形、フーリエ解析結 果、ウェーブレット解析結果を比較し易くするため、時 間軸、周波数軸を同じスケールとした。ウェーブレット 解析結果は縦軸に周波数、横軸に対象波形に対応した時 間をとり、濃淡で各周波数成分の振幅強度を表している。 まず、フーリエ解析結果からは、ハードスイッチングで は $5.2 \mathrm{MHz}$ と $10.4 \mathrm{MHz}$ 付近でピークが現れ、ソフトス イッチングでは、 $1 \mathrm{MHz}$ 付近 でピークが現われること が確認できる。また、 $1 \mathrm{MHz}$ 付近を除き、ソフトスイッチ ング方式では全周波数にわたってスペタトルが低減して おりソフトスイッチングの高調波抑制効果が確認できる。 これに加えて、ウェーブレット解析結果からは次のよう な新たな情報が得られる。ハードスイッチングの $5.2 \mathrm{MHz}$ と $2 \mathrm{MHz}$ の 2 つの周波数は、スイッチング時に の時刻 で同時に生じている。この $5.2 \mathrm{MHz}$ は、フーリエ解析で は高いピークとして現れているが、特に高いピークが存
在したのではなく、減衰時間が約 $7.6 \mu \mathrm{sec}$ の $2 \mathrm{MHz}$ に 対して $5.2 \mathrm{MHz}$ は約 $10.8 \mu \mathrm{sec}$ までと長く、それが積分 值として現れたためと考えられる。また、フーリエ解析 結果からだけでは確認できなかったが、ソフトスイッチ ングを行ってもハードスイッチングと同様に $2 \mathrm{MHz}$ 付近 で減衰していく同じ様な周波数帯の存在が確認された これは外部回路的に抑制できない、すなわち IGBT 内部 に起因するものではないかと推察される。そして、この $2 \mathrm{MHz}$ 付近の現象は IGBT の寄生容量と配線インダクタ ンスの共振であることが確認された。電流波形からも電 圧波形と同様のことが確認されたがここでは詳細を述べ ることは割愛させて頂くことにする。

以上に示したように、ウェーブレット変換による時間 周波数解析を用いることにより、実測波形やフーリエ解 析結果だけでは解明できなかった内部回路的な現象を捉 えることが可能となった。

3.2 高周波リンク DC-AC コンバータから発生する高 調波の時間周波数解析 ここでは、図 7 に示寸高周波 $\mathrm{AC}$ リンク DC-AC コンバータの出力波形 Vok含まれる高調 波についてウェーブレット解析を行つた結果を報告する。

この高周波 $\mathrm{AC}$ リン $\mathrm{DC}-\mathrm{AC}$ コンバータの制御は、循 環電流を除去できる 2 次側位相シフト PWM 制御と称す る制御方式で行っている。

図 8(a) は、高周波 AC リンク DC-AC コンバータの 製作当初の出力 Voの実測波形及び、フーリ工解析結果、 ウェーブレット解析結果である。また、このときの高調 波含有率を表 3 に示す。この段階では、まだ多くの高調 波を含んでいたため、まず実波形とフーリエ解析結果を もとに考察を行った。この結果、 $20 \mathrm{kHz}$ と $3 \mathrm{kHz}$ の高 調波成分が大きくなっており、前者は高周波 $\mathrm{AC}$ リンク DC-AC コンバータの動作周波数であり、後者は出力電圧 のゼロクロス付近で生じている歪みが原因であると推察 された。そして、ゼロ付近の歪みを改善するためフィル 


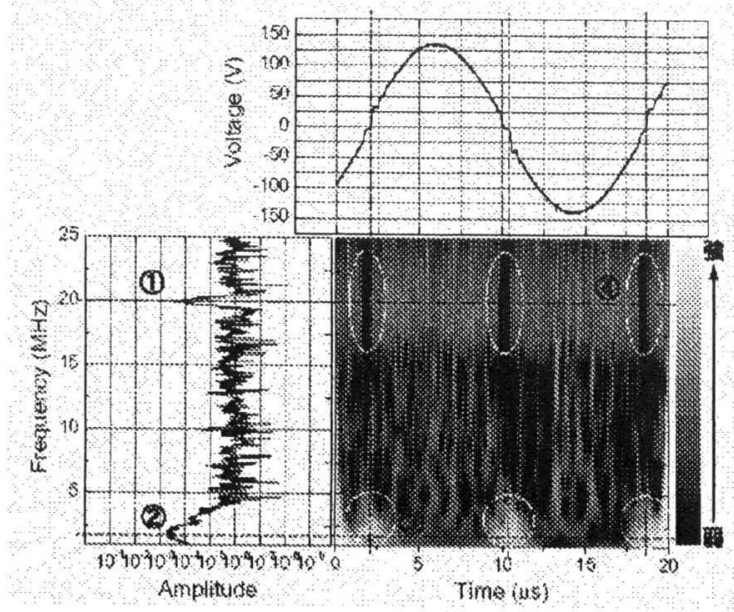

(a) 改良前

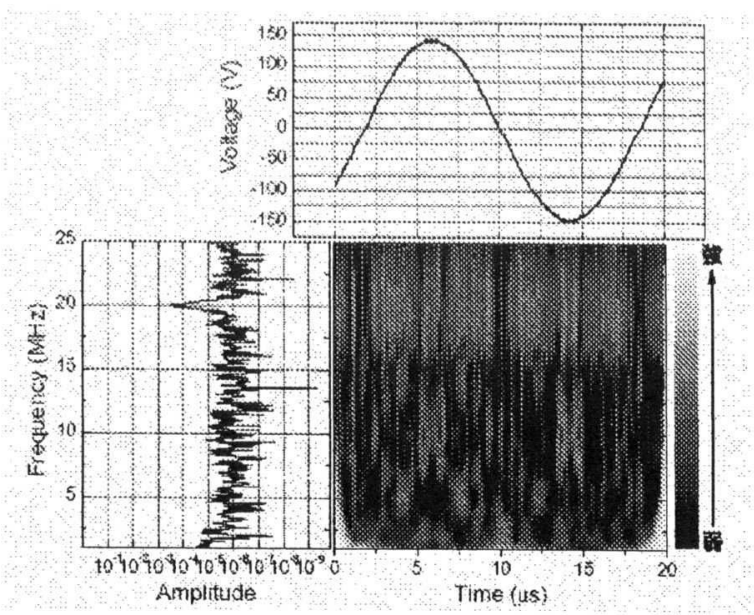

(b) 改良後

図 8 高周波 $\mathrm{AC}$ リンク DC-AC コンバータの時間周波数解析

表 2 改良後の出力波形の高調波含有率

\begin{tabular}{|c|c|c|}
\hline 高調波含有率 & 電圧 $(\%)$ & 電流 $(\%)$ \\
\hline 総合 & 1.06 & 1.54 \\
\hline 3 次 & 0.76 & 1.17 \\
\hline 5 次 & 0.33 & 0.92 \\
\hline 7 次 & 0.45 & 0.07 \\
\hline
\end{tabular}

表 3 製作当初の出力波形の高調波含有率

\begin{tabular}{|c|c|c|}
\hline 高調波含有率 & 電圧 $(\%)$ & 電流 $(\%)$ \\
\hline 総合 & 4.01 & 2.73 \\
\hline 3 次 & 2.86 & 1.12 \\
\hline 5 次 & 1.65 & 1.35 \\
\hline 7 次 & 1.03 & 1.27 \\
\hline
\end{tabular}

タの再設計をするなど改善策を試行錯誤的に行ったが根 本的な解決を図ることはできなかった。そこで、ウェー ブレット解析結果を重ねて考察を加えると、 $3 \mathrm{kHz}$ の高調 波は $t=2,11,18 \mathrm{msec}$ で発生していることから出力電 圧のゼロクロス付近で生じている歪みが原因であると断 定できた。そして、動作周波数である $20 \mathrm{kHz}$ を見ると出 力電圧がゼロクロスする時刻である $t=2,11,18 \mathrm{msec}$ の 近傍で途切れていることが確認された。これは、これ らの時刻において高周波 $\mathrm{AC}$ リンク DC-AC コンバータ の動作自身が停止してしまっており出力電圧の制御が行 えていなかったものと判断できる。この得られた知見を もとに、DSP を含めた制御回路を調査した結果、出力電 圧のゼロクロス付近の小さな電圧を制御するのに必要な 最小 PWM 信号 (約 $12 \mu \mathrm{s}$ ) が直接 DSP から得ることがで きないようになっていた。

そこで、DSP の負担を軽減させその性能をフルに発揮 できるよう DSP 周辺回路の改良を行い、10 $\mu \mathrm{s}$ の PWM 信号まで出力できるようにした。主回路はそのままで、制 御回路のみを改良した高周波 $\mathrm{AC}$ リンク DC-AC コンバー 夕の出力電圧波形、フーリエ解析結果、ウェーブレット
解析結果を図 8(b) に示す。また、このときの高調波含有 率を表 2 に示す。これらの結果から、出力電圧のゼロク ロス付近の波形の歪みは改善され、高調波含有率も大き く減少したことが確認された。また、ウェーブレット解 析結果から $20 \mathrm{kHz}$ の成分がほぼ連続的に発生するように なっていることも確認され、これにより高周波 $\mathrm{AC}$ リン ク DC-AC コンバータの出力電圧がゼロクロス付近でも 連続して制御・動作できていると判断できる。このよう に、ウェーブレット解析を用いると、高調波、ノイズ発 生の原因が、制御回路的な要因か主回路的な要因かを判 別することができ、的確な解決法を決定できるようにな ると言える。

\section{3 電化製品の入力波形に含まれる高調波の時間周波}

数解析 ここでは、電化製品を使用する際に問題となっ てくる入力波形に対して行った解析結果を示す。図 9 に 開発段階の電化製品の入力電流波形を示す。この段階で は、15 次と 17 次の周波数が高くなって抢り規定をクリ アされていなかった。実波形とフーリエ解析結果だけで は、この 2 つ周波数が何が原因で、どこで発生してい るかが判断できないため、いろいろと試行錯誤を繰り返 すと理由は特定できないが結果的にはこの周波数は抑え られるという状況であった。そこで、ウェーブレット解 析を行い原因究明を試みた。実波形から見ると、電流の 立ち上がり時の影響が強いと思われていたが、ウェーブ レット解析結果を見ると、この周波数の発生している䇢 所は、電流波形の中腹近辺で生じているわずかな歪みが 原因であることがはっきりと認識できた。そして、この 箇所について詳細な調査をした結果、負荷の変化に伴い 制御系を切り替える期間であると確認できたため、その 䇢所の切り替えをスムーズになるように改良したところ これらの周波数が削減された。このように、高調波の発 生場所を完全に特定することにより、的確な改善策が施 された一例であると言える。 $3 \mathrm{~mm}$ 


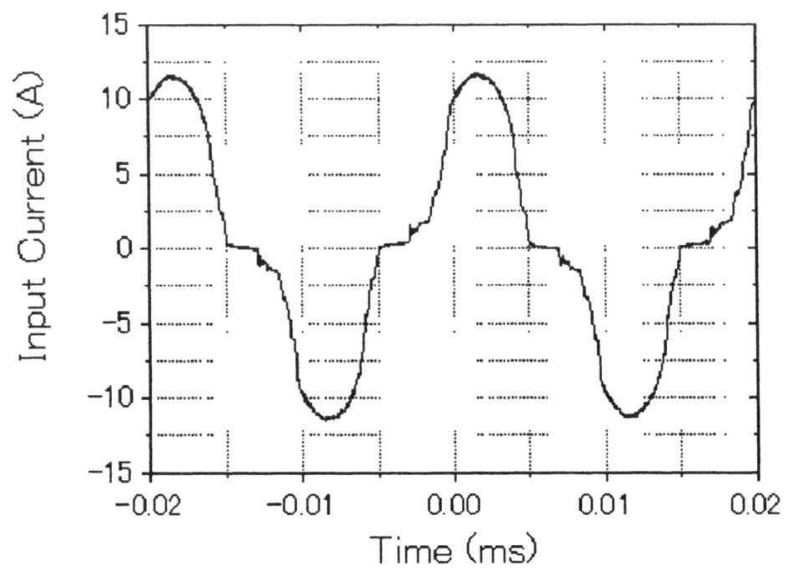

(a) 実測波形 (スム・ジング)

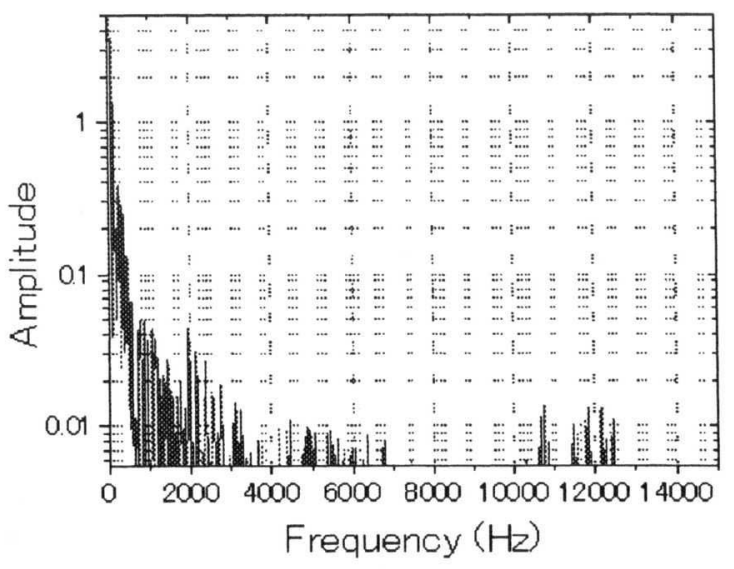

(b) FFT 波形

図 9 電化製品の大力波形に含まれる高調波

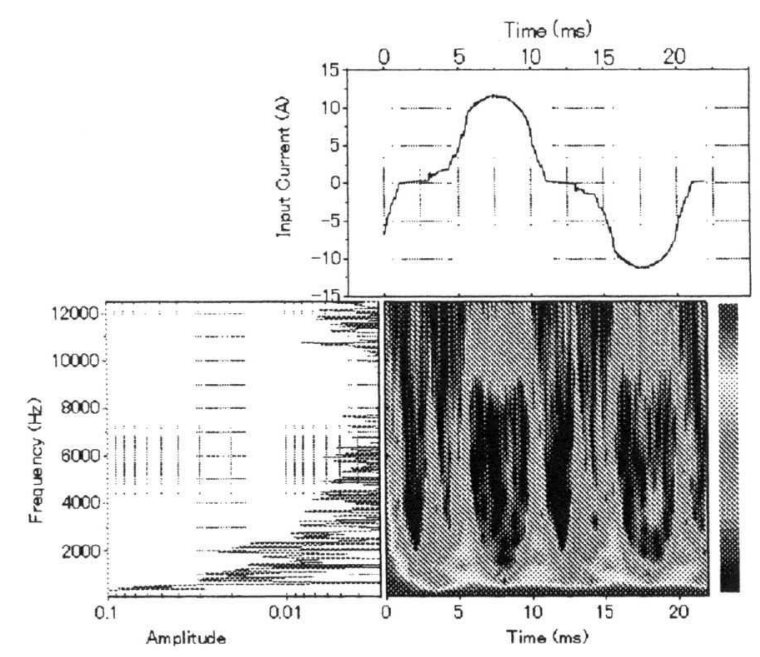

図 10 電化製品への入力電流波形に含まれる高調波の時 間周波数解析

\section{4. まとめ}

本論文では、高調波解析の新しい手法としてウェーブ レット変換による時間周波数解析を提案し、これにより 得られる解析結果がどのように現象を解明し、問題解決 の一助となるかについて適用例を示しながらその成果に ついて報告した。今回の解析結果例から得られた特幑を まとめると以下のようになる。

○スイッチング時等の過渡的現象に対する解析ができる。 これにより見いだされる特徴的な高調波が、実際に用い る半導体素子内部の状態に起因するものなのか、また回 路構成上の要因によるものなのかといった詳細な考察が できる。

時間軸情報により問題の抽出、的確な問題解決ができ る。

これらは、実際のパワエレ機器設計において施される高 調波フィルタなど様々な対策装置の簡略化や設計の最適
化などに有効であり、機器全体の低コスト化や小型・軽 量化など周辺回路も含めた改良の手段となると期待され る。また、半導体素子の特性や回路の寄生成分による影 響を的確に捉えていくことにより、使用する素子の選択 や変換器の実装面での改善など主回路部分の改良にも貢 献することが期待できる。

また、実際に放射される電磁ノイズの測定、解析を実 施すれば、電磁ノイズと電圧、電流高調波との因果関係や 電磁ノイズ発生源の特定などが行える可能性が高く、電 磁ノイズの様相を調べる上でも大きな効果を発揮し得る ものと考えられる。

これらを今後の課題とし、さらなるウェーブレット変 換による時間周波数解析の有効性や適用法について検討 していく予定である。

\section{参考文献}

(1) 赤松 他, ”変換器出力高調波低隇の検討における時間周 波数解析の適用”, 電気学会論文誌 B, Vol.121-B, No.4, pp.442-448, 2001.

（2）赤松他, ”電力変換装置から発生する高調波の時間周波数 解析”, 電気学会論文誌 D, Vol.120-D, No.7, pp.949-950, 2000 .

(3) Keiji Akamatsu, et.al., "Application of the timefrequency analysis for EMC study on power conversion system", AP-RASC'01-Tokyo, p.145, 2001.

(4) 道平 他, ”2 次側位相シフト PWM 制御を行う部分共振 型高周波リンク DC-AC コンバータの動作解析”, 電気 学会論文誌 D, Vol.117-D, No.12, pp.1503-1510, 1997. 


\section{【討 論 】 \\ 同志社大学 井上馨}

【質問 1】マザーウェーブレットと時間空の取り方が重 要だと思いますがこれらの選び方の指針はあるのでしょう か?

【回答 1】取り扱う現象や解析の目的、例えば、ノイズ 除去を目的として行う場合や単にノイズの連続的な現象の 解明などのように異なれば用いるマザーウェーブレットは 変わってきます。どのマザーウェーブレットがどの応用に 適しているかという議論は、数学の分野で検討されていま す。今回のような高調派の連続的な解析には、Gabor のマザ 一ウェーブレットが適しているといらことなので、本研究 ではこれを用いています。

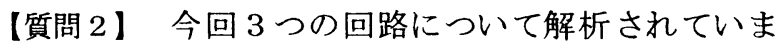
すが、すべての回路に対して同じマザーウェーブレッ 卜を使用されているのでしょうか? 回路構成によっ ては、マザーウェーブレットを変更する必要はある か?

【回答 2】回路が異なっても解析する目的、寸なわ ち、高調波の連続的な周波数解析といらものが同じな らばマザーウェーブレットは変更する必要はありま せん。回路の波形により解析する周波数帯が大きく異 なる場合 (インバータの動作周波数レベルを解析する か、インバータの出力周波数レベルを解析するか)、 周波数の解析範囲だけは変更しなければなりません。

【質問 3 】回路素子の特性や、入力によっては非線形現象 が生じる回路が存在しますが、このような回路の解析は可 能でしょうか?

【回答 3 】ウェーブレット解析では、現象の生起時間の特 定や不連続点の検出も可能になりますので、非線形現象に ついても解析は可能と考えています。

\section{大阪工業大学 木村紀之}

【質問 1】 ウェーブレット変換をするのにどのよう なソフトウェアを使用しているのか? 時間はどの程 度かかるのか?

【回答 1】ソフトウェアは、C 言語で自作したもの を使用しています。解析時間は、サンプリング周波数 $25 \mathrm{MHz} 、$ データ 1000 サンプルを Pentium550MHzで解 析すると約 1 分程度となります。 